\title{
Pediococcus cellicola sp. nov., a novel lactic acid coccus isolated from a distilled-spirit-fermenting cellar
}

\author{
Bin Zhang, ${ }^{1,2}$ Huichun Tong ${ }^{1}$ and Xiuzhu Dong ${ }^{1}$
}

Correspondence

Xiuzhu Dong

dongxz@sun.im.ac.cn
Pediococci are spherical lactic acid bacteria, with cells arranged mainly in pairs or tetrads. They produce lactic acid exclusively from glucose fermentation, and inhabit fermentable-sugar-rich niches, such as plant materials and fermented foods (Garvie, 1986), especially pickles and preserved meat. In the food industry, they have been used as starter cultures in some kinds of sausage fermentation. However, pediococci can also cause quality problems for brewers when present in beer and wines (Gardner et al., 2001; Lonvaud-funel, 1999).

To date seven Pediococcus species have been described: Pediococcus acidilactici, Pediococcus claussenii (Dobson et al., 2002), Pediococcus damnosus, Pediococcus dextrinicus, Pediococcus inopinatus, Pediococcus parvulus and Pediococcus pentosaceus. A species that was previously designated as belonging to the genus Pediococcus, Pediococcus urinaeequi, was recently reclassified as Aerococcus urinaeequi (Felis et al., 2005). On the basis of $16 \mathrm{~S}$ rRNA gene similarity, the genus Pediococcus was grouped in the Lactobacillus casei branch of the lactic acid bacteria (Collins et al., 1991). Within the

Published online ahead of print on 10 June 2005 as DOI 10.1099/ ijs.0.63778-0.

The GenBank/EMBL/DDBJ accession numbers for the 16S rRNA gene sequences of strains $Z-8^{\top}$ and $Z-1$ are AY956788 and AY956791, respectively. genus Pediococcus, $P$. damnosus, $P$. inopinatus and $P$. parvulus formed a closely related cluster, whereas $P$. acidilactici, P. claussenii and P. pentosaceus formed a second cluster, and $P$. dextrinicus, a distinct Pediococcus species, was clustered with some Lactobacillus species.

Chinese liquor is a kind of wine produced by solidified fermentation of grain. During an investigation of lactic acid bacteria in Chinese wine breweries, we isolated several dozen Pediococcus strains. Two strains from a brewery in Hebei Province, China, exhibited phenotypic characteristics that differed from those of all existing Pediococcus species. Phylogenetic analysis based on 16S rRNA gene sequence similarity and DNA-DNA hybridization also indicated that the two strains represented a novel species of the genus Pediococcus.

P. damnosus LMG $11484^{\mathrm{T}}$, P. inopinatus LMG $11409^{\mathrm{T}}$ and $P$. parvulus LMG $11486^{\mathrm{T}}$ were kindly provided by the Laboratory of Microbiology, Ghent University (BCCM/ LMG, Ghent, Belgium). Strains Z-1 and Z-8 ${ }^{\mathrm{T}}$ were originally isolated from the walls of a distilled-spirit-fermenting cellar in Hebei Province, China. They were isolated and purified by streaking the samples on de Man-Rogosa-Sharpe (MRS) agar (de Man et al., 1960). The strains were routinely grown aerobically on the same medium at $37^{\circ} \mathrm{C}$ unless stated otherwise. The end-products of glucose fermentation in 
tryptone-peptone-yeast extract-glucose (TPYG) liquid were detected by using a gas chromatograph (GC-14B; Shimadzu). Isomers of lactate formed from glucose were determined by using a D-/L-lactic acid test kit (Roche Diagnostics). Catalase activity was determined by adding $15 \%(\mathrm{v} / \mathrm{v})$ hydrogen peroxide to the fresh cultures. Temperature profiles were determined by using a water bath with a temperature gradient. Growth at various $\mathrm{pH}$ values was determined in TPYG liquid adjusted with $\mathrm{HCl}$ or $\mathrm{NaOH}$. Tolerance of ethanol was determined by monitoring growth in TPYG liquid with different concentrations of ethanol $(\mathrm{v} / \mathrm{v})$. The generation time was determined by monitoring the $\mathrm{OD}_{600}$ of an MRS liquid culture at $37^{\circ} \mathrm{C}$ for $24 \mathrm{~h}$. Sugar fermentation patterns were determined by using both conventional methods (Garvie, 1986) and the API 50 $\mathrm{CH}$ system (bioMérieux) after $24 \mathrm{~h}$ incubation at $37^{\circ} \mathrm{C}$. All of the tests were performed in duplicate.

Genomic DNA was extracted and purified as described by Marmur (1961). The 16S rRNA gene was amplified by PCR using the genomic DNA as template, and sequenced using an ABI PRISM 377XL DNA sequencer. The 16S rRNA gene sequences of the most-related species were retrieved from GenBank and aligned, and similarity analysis was performed using the CLUSTAL_X program (Thompson et al., 1997). A phylogenetic tree was constructed using the neighbour-joining method (Saitou \& Nei, 1987), implemented in the MEGA2 program (Kumar et al., 2001). The stability of the clustering of the tree was evaluated by bootstrap analysis of 1000 datasets. DNA G + C content was determined by using the thermal denaturation method (Marmur \& Doty, 1962). DNA-DNA relatedness was determined on the basis of DNA-DNA liquid reassociation rate (De Ley et al., 1970), using a DU-800 spectrophotometer (Beckman) with a thermal controller.

Cells of the two isolates were Gram-positive, non-sporeforming, non-motile cocci, occurring in pairs or tetrads. Catalase activity was negative and the strains were facultatively anaerobic. These characteristics indicated that the two isolates were members of the genus Pediococcus. Product determination showed that the two strains produced lactic acid [about 50\% (-)-D-/50\%(+)-L-] exclusively from glucose fermentation without gas. By using both conventional methods and the API $50 \mathrm{CH}$ system, the two strains were shown to use rhamnose, ribose, D-xylose and L-xylose as sole carbon and energy sources, which differentiated them from phylogenetically closely related species (Table 1). Fermentation of D-arabinose, L-arabinose and methyl $\alpha$-D-glucoside was variable in the two strains. Both strains hydrolysed aesculin but not arginine. In addition, the two strains tolerated $10 \%$ ethanol $(\mathrm{v} / \mathrm{v})$, in accordance with their original habitat. The mean generation time of the two strains was $1.09 \pm 0.06 \mathrm{~h}$ when cultured aerobically, and $1 \cdot 01 \pm 0 \cdot 06 \mathrm{~h}$ when cultured anaerobically.

The complete 16S rRNA gene sequence of the novel strain $\mathrm{Z}-8^{\mathrm{T}}$ was compared with those of the most closely related species retrieved from GenBank. A phylogenetic tree rooted with Bacillus subtilis NCDO $1769^{\mathrm{T}}$ was constructed (Fig. 1). It was shown that strain $\mathrm{Z}-8^{\mathrm{T}}$ clustered within the $P$. damnosus $-P$. inopinatus- $P$. parvulus group, with $16 \mathrm{~S}$ rRNA gene sequence similarities ranging from 98.3 to $98.5 \%$. The two novel isolates had a partial $16 \mathrm{~S}$ rRNA gene sequence similarity of $99 \cdot 5 \%$. The mean DNA G $+\mathrm{C}$ content of the two novel strains was $38 \pm 1 \mathrm{~mol} \%$ ( $37 \mathrm{~mol} \%$ for strain $\mathrm{Z}-8^{\mathrm{T}}$ and $39 \mathrm{~mol} \%$ for strain Z-1), which was within the range for the genus Pediococcus (34-42 mol\%). DNA-DNA relatedness between the novel strains and their phylogenetically closest related species was determined at a hybridization temperature of $67^{\circ} \mathrm{C}$. The DNA-DNA relatedness between the two novel isolates, $\mathrm{Z}-1$ and $\mathrm{Z}-8^{\mathrm{T}}$, was $91 \%$, indicating a homogeneous genetic group. However, the DNA-DNA relatedness between strain $\mathrm{Z}-8^{\mathrm{T}}$ and $P$. damnosus LMG $11484^{\mathrm{T}}$, P. inopinatus LMG $11409^{\mathrm{T}}$ and $P$. parvulus LMG $11486^{\mathrm{T}}$ was $19 \pm 4,35 \pm 5$ and $31 \pm 5 \%$, respectively, lower than the DNA-DNA relatedness threshold $(70 \%)$ for a species.

Although strain Z-8 ${ }^{\mathrm{T}}$ had higher $16 \mathrm{~S}$ rRNA gene sequence similarities with $P$. damnosus $\mathrm{LMG} 11484^{\mathrm{T}}(98 \cdot 3 \%), P$. inopinatus LMG $11409^{\mathrm{T}}(98.5 \%)$ and $P$. parvulus LMG $11486^{\mathrm{T}}(98 \cdot 3 \%)$, the following characteristics verified their separate species status: low DNA-DNA relatedness, different phenotypic characteristics such as fermentation of rhamnose, ribose, D-xylose and L-xylose, and the ability to grow in $10 \%$ ethanol $(\mathrm{v} / \mathrm{v})$ (Table 1$)$.

Based on the phenotypic characteristics, phylogenetic relationship and DNA-DNA relatedness, a novel species

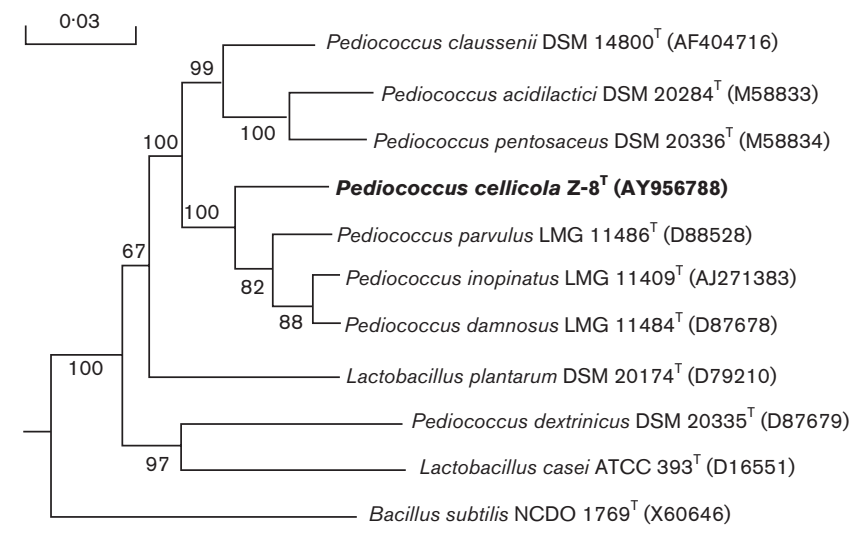

Fig. 1. Dendrogram based on $16 \mathrm{~S}$ rRNA gene sequence similarity in a consensus length of $1400 \mathrm{bp}$, showing the phylogenetic relationships between $P$. cellicola sp. nov. Z- $8^{\top}$ and related lactic acid bacterial species. The tree was rooted with B. subtilis NCDO $1769^{\top}$ and constructed using the neighbourjoining method with bootstrap values calculated from 1000 trees. Numbers at branch points are percentage levels of bootstrap support. GenBank accession numbers of 16S rRNA gene sequences are given in parentheses. Bar, 3\% sequence divergence. 
Table 1. Differential phenotypic characteristics of $P$. cellicola sp. nov. and phylogenetically closely related species

Taxa: 1, P. cellicola Z-8 ${ }^{\mathrm{T}}$; 2, P. cellicola Z-1; 3, P. damnosus (data from Back, 1978); 4, P. inopinatus (Back, 1978); 5, P. parvulus (Gunther \& White, 1961). The data were also verified in this study by using conventional methods.,$+>90 \%$ of strains positive;,$-<10 \%$ of strains positive; $\mathrm{D}+, 50-89 \%$ of strains positive. In acid production tests: C, by using conventional methods; API, by using the API 50 $\mathrm{CH}$ system; no indication, by using both methods.

\begin{tabular}{|c|c|c|c|c|c|}
\hline Characteristic & 1 & 2 & 3 & 4 & 5 \\
\hline \multicolumn{6}{|l|}{ Acid production from: } \\
\hline D-Arabinose & + & - & $-(\mathrm{C})$ & $-(\mathrm{C})$ & $-(\mathrm{C})$ \\
\hline L-Arabinose & + & - & $-(\mathrm{C})$ & $-(\mathrm{C})$ & $-(\mathrm{C})$ \\
\hline Dextrin & $-(\mathrm{C})$ & $-(\mathrm{C})$ & $-(\mathrm{C})$ & $\mathrm{D}+(\mathrm{C})$ & $-(\mathrm{C})$ \\
\hline Lactose & + & + & $-(\mathrm{C})$ & $+(\mathrm{C})$ & $-(\mathrm{C})$ \\
\hline Maltose & + & + & $\mathrm{D}+(\mathrm{C})$ & $+(\mathrm{C})$ & $+(\mathrm{C})$ \\
\hline Melezitose & $-(\mathrm{C})$ & $-(\mathrm{C})$ & $\mathrm{D}+(\mathrm{C})$ & $-(\mathrm{C})$ & $-(\mathrm{C})$ \\
\hline Rhamnose & + & + & $-(\mathrm{C})$ & $-(\mathrm{C})$ & $-(\mathrm{C})$ \\
\hline Ribose & + & $+(\mathrm{C}),-(\mathrm{API})$ & $-(\mathrm{C})$ & $-(\mathrm{C})$ & $-(\mathrm{C})$ \\
\hline Sucrose & + & + & $\mathrm{D}+(\mathrm{C})$ & $\mathrm{D}+(\mathrm{C})$ & $-(\mathrm{C})$ \\
\hline D-Xylose & + & + & $-(\mathrm{C})$ & $-(\mathrm{C})$ & $-(\mathrm{C})$ \\
\hline L-Xylose & + & + & $-(\mathrm{C})$ & $-(\mathrm{C})$ & $-(\mathrm{C})$ \\
\hline Methyl $\alpha$-D-glucoside & $-(\mathrm{C})$ & $+(\mathrm{C})$ & $\mathrm{D}+(\mathrm{C})$ & $\mathrm{D}+(\mathrm{C})$ & $\mathrm{D}+(\mathrm{C})$ \\
\hline \multicolumn{6}{|l|}{ Growth at/in: } \\
\hline $\mathrm{pH} 7 \cdot 0$ & + & + & - & + & + \\
\hline $10 \%$ Ethanol $(\mathrm{v} / \mathrm{v})$ & + & + & $+^{*}$ & $-*$ & $-*$ \\
\hline $30^{\circ} \mathrm{C}$ & + & + & - & + & + \\
\hline
\end{tabular}

${ }^{\star}$ Data from this study.

of the genus Pediococcus, Pediococcus cellicola sp. nov., is proposed.

\section{Description of Pediococcus cellicola sp. nov.}

Pediococcus cellicola (cel.li.co'la. L. n. cella a storeroom for wine and food; L. suff. -cola from L. n. incola an inhabitant, dweller; N.L. n. cellicola an inhabitant of a storeroom, indicating that the strains were originally isolated from a distilled-spirit-fermenting cellar).

Gram-positive, non-spore-forming, non-motile, spherical cells, $0 \cdot 6-1 \mu \mathrm{m}$ in diameter after $24 \mathrm{~h}$ incubation in aerobic MRS liquid at $37^{\circ} \mathrm{C}$. Cells occur in pairs or tetrads. Colonies are greyish white, low-convex, circular, entire, opaque and about $1 \mathrm{~mm}$ in diameter after $24 \mathrm{~h}$ cultivation on MRS plates at $37^{\circ} \mathrm{C}$. Catalase-negative. Facultatively anaerobic. Lactic acid [about $50 \%(-)-\mathrm{D}-/ 50 \%(+)$-L-] is produced from glucose fermentation, but not gas. Growth occurs at $13-44^{\circ} \mathrm{C}$, with an optimum at $30-37^{\circ} \mathrm{C}$. Optimum $\mathrm{pH}$ for growth is $6 \cdot 0-6 \cdot 8$; no growth occurs at $\mathrm{pH} 3 \cdot 8$ and $8 \cdot 2$. Grows in $10 \%$ ethanol (v/v) but not in $10 \% \mathrm{NaCl}(\mathrm{w} / \mathrm{v})$. Aesculin but not arginine is hydrolysed. Acid is produced from galactose, glucose, fructose, mannose, methyl $\alpha$-Dmannoside, methyl $\alpha$-D-glucoside, $N$-acetylglucosamine, arbutin, salicin, cellobiose, gentiobiose, D-tagatose, 2ketogluconate, rhamnose, ribose, D-xylose, L-xylose, lactose, maltose, trehalose and sucrose. Acid is not produced from glycerol, erythritol, adonitol, methyl $\beta$-D-xyloside, sorbose, dulcitol, inositol, mannitol, sorbitol, amygdalin, aesculin, inulin, melezitose, raffinose, starch, glycogen, xylitol, Dturanose, D-lyxose, D-fucose, L-fucose, D-arabitol, L-arabitol, gluconate, 5-ketogluconate or dextrin. Fermentation of D-arabinose, L-arabinose and methyl $\alpha$-D-glucoside is variable. Strain $\mathrm{Z}-8^{\mathrm{T}}$ ferments $\mathrm{D}$-arabinose and L-arabinose but not methyl $\alpha$-D-glucoside, whereas the reverse applies for strain Z-1. Mean DNA G $+\mathrm{C}$ content is $38 \pm 1 \mathrm{~mol} \%$ $\left(37 \mathrm{~mol} \%\right.$ for strain $\left.\mathrm{Z}-8^{\mathrm{T}}\right)$.

The type strain is $\mathrm{Z}-8^{\mathrm{T}}$ (=AS $1.3787^{\mathrm{T}}=\mathrm{LMG} 22956^{\mathrm{T}}$ ), which was isolated from a distilled-spirit-fermenting cellar in Hebei Province, China.

\section{Acknowledgements}

This study was supported by a grant from the National Natural Science Foundation of China (No. 30230020).

\section{References}

Back, W. (1978). Zur Taxonomie der Gattung Pediococcus. Phänotypische und genotypische Abgrenzung der bisher bekannten Arten sowie Beschreibung einer neuen bierschädlichen Art: 
Pediococcus inopinatus. Brauwissenschaft 31, 237-250, 312-320 (in German)

Collins, M. D., Rodriguez, U., Ash, C., Aguirre, M., Farrow, J. A. E., Martinez-Murcia, A., Philips, B. A., Williams, A. M. \& Wallbanks, S. (1991). Phylogenetic analysis of the genus Lactobacillus and related lactic acid bacteria as determined by reverse transcriptase sequencing of $16 \mathrm{~S}$ rRNA. FEMS Microbiol Lett 77, 5-12.

De Ley, J., Cattoir, H. \& Reynaerts, A. (1970). The quantitative measurement of DNA hybridization from renaturation rates. Eur J Biochem 12, 133-142.

de Man, J. C., Rogosa, M. \& Sharpe, M. E. (1960). A medium for the cultivation of lactobacilli. J Appl Bacteriol 23, 130-135.

Dobson, C. M., Deneer, H., Lee, S., Hemmingsen, S., Glaze, S. \& Ziola, B. (2002). Phylogenetic analysis of the genus Pediococcus, including Pediococcus claussenii sp. nov., a novel lactic acid bacterium isolated from beer. Int J Syst Evol Microbiol 52, 2003-2010.

Felis, G. E., Torriani, S. \& Dellaglio, F. (2005). Reclassification of Pediococcus urinaeequi (ex Mees 1934) Garvie 1988 as Aerococcus urinaeequi comb. nov. Int J Syst Evol Microbiol 55, 1325-1327.

Gardner, N. J., Savard, T., Obermeier, P., Caldwell, G. \& Champagne, C. P. (2001). Selection and characterization of mixed starter cultures for lactic acid fermentation of carrot, cabbage, beet and onion vegetable mixtures. Int J Food Microbiol 20, 261-275.
Garvie, E. I. (1986). Genus Pediococcus Claussen 1903, 68 ${ }^{\mathrm{AL}}$. In Bergey's Manual of Systematic Bacteriology, vol. 2, pp. 1075-1079. Edited by P. H. A. Sneath, N. S. Mair, M. E. Sharpe \& J. G. Holt. Baltimore: Williams \& Wilkins.

Gunther, H. L. \& White, H. R. (1961). The cultural and physiological characters of the pediococci. J Gen Microbiol 26, 185-197.

Kumar, S., Tamura, K., Jakobsen, I. B. \& Nei, M. (2001). MEGA2: molecular evolutionary genetics analysis software. Bioinformatics 17, 1244-1245.

Lonvaud-funel, A. (1999). Lactic acid bacteria in the quality improvement and depreciation of wine. Antonie van Leeuwenhoek 76, 317-331.

Marmur, J. (1961). A procedure for the isolation of deoxyribonucleic acid from microorganisms. J Mol Biol 3, 208-218.

Marmur, J. \& Doty, P. (1962). Determination of the base composition of deoxyribonucleic acid from its thermal denaturation temperature. J Mol Biol 5, 109-118.

Saitou, N. \& Nei, M. (1987). The neighbor-joining method: a new method for reconstructing phylogenetic trees. Mol Biol Evol 4, 406-425.

Thompson, J. D., Gibson, T. J., Plewniak, F., Jeanmougin, F. \& Higgins, D. G. (1997). The CLUSTAL_X Windows interface: flexible strategies for multiple sequence alignment aided by quality analysis tools. Nucleic Acids Res 25, 4876-4882. 